\title{
The Information Security Specialty Education Reform Aimed at Improving Engineering Practice Ability
}

\author{
Lian Wang
}

\begin{abstract}
The current situation and the background of information security talents education are summarized in this paper. The problems of information security engineering practical education existed are analyzed. And some ideas and measures are proposed to improve the information security engineering practical ability. The final purposes are to make the engineering practical education and the engineering education standard connected to educate more information security professionals met with the requirements of domestic and external requirements.
\end{abstract}

Index Terms - Information security, engineering practice education, engineering standard, ability.

\section{CURRENT SITUATION AND BACKGROUND}

\section{A. Information Security Professionals Have Become the Core of the National Competition}

International conflicts about information security have become drastically, and achieving the information security control power is the strategic high spot. Obama Administration strengthens information security and regards it as an important strategy to revitalize US economic prosperity and the national security. In addition, United States Cyber Command has been established. The US Surveillance Program (PRISM) incident has fully exposed the American hegemony behaviors that monitor the whole world network. May 16, 2011, the United States issued "International Strategy for Cyberspace", and on July 14, "Cyberspace Operations Strategy" issued. All regard strengthening information security education and cultivating professionals as the emphasis of safeguarding cyberspace strategy to assure the absolute predominance of the whole world control.

Information security has become an important part of our national security, and is an important national policy that to defend the national cyberspace sovereignty. The management team with advanced information security professional knowledge is required to build and maintain the national important information systems, and infrastructure. The 18th National Congress of the Communist Party of China pointed out that "the world is still far from tranquil... food security, energy security, network security and other global issues have become more and more prominent" [1]. At the same time, the

Manuscript received September 26, 2015; revised March 18, 2016. This work is supported by Chong Qing Higher School Teaching Research Reform Projects (Grant No. 143004, 153069, 141010), and Program for Innovation Team Building at Institutions of Higher Education in Chongqing (Grant No. KJTD201310).

Lian Wang is with College of Computing Science and Technology, Chongqing University of Posts and Telecommunications, Chongqing 400065, P. R. China (e-mail: wanglian@cqupt.edu.cn). report requires that "build the next generation information infrastructure, develop modern information technology industrial system, improve information security guarantee system, promote information network technology widely used...pay high attention to ocean security, space security and cyberspace security".

\section{B. The Rapid Information Technology Development, the Serious Shortage of Information Security Professionals, and Urgent Need of Talents to Companies}

Now, information security development lags behind the conventional information technology, and there are a large number of security requirements and risks have been precipitated. The development of information technology and application is at a tremendous pace. Security should be integrated at the beginning. Information technology is continuously deepen in industry application, and information security change from potential demand to real demand, the severe shortage of industry professional is obvious, as shown in Table I .

CCID (China Center for Information Industry Development) data statistics suggested that international information security industry growth at $9 \%$,in domestic IT industry, information security is a high-growth industry, and its compound annual growth rate has reached $21 \%$ ( 11.174 billion in 2010, 13.553 billion in 2011, 16.658 billion in 2012 ). It is much higher than that of IT growth in the same period. Only take our country's information security rank protection important information system (unclassified) as an example, the defined levels are more than 50000, and the preliminary statistics that the demand of information security professionals is reached as high as millions. Currently, the number of information security graduates and professional structure cannot meet the national security requirement.

\section{Innovative Spirit and Practical Ability Is the Basic} Quality of the Information Security Practitioner,

Enhancing Engineering Practical Ability of Information

Security Student Is an Important Way to Cultivate

Innovative Professional

Information security is a comprehensive interdiscipline field, except the common characteristics of engineering education, information security professional cultivation has its unique characteristics: Information security field knowledge covers widely and is updated fast; Information security education focus on application and practical ability especially; the requirements of information security professional are diverse and hierarchical. For information security, engineering practical teaching cultivates students' innovative consciousness. Innovative spirit and innovative ability are particularly important. Improving the practical 
teaching quality and enhancing students' engineering practice ability are the primary tasks of current information security specialty building [2]-[4]

TABLE I: THE SUPPLY AND DEMAND STATISTICS OF INFORMATION SECURITY TALENTS

\begin{tabular}{|c|c|c|c|}
\hline $\begin{array}{l}\text { College } \\
\text { Quantity }\end{array}$ & $\begin{array}{l}\text { Students } \\
\text { Quantity }\end{array}$ & $\begin{array}{c}\text { Industry } \\
\text { Requirements }\end{array}$ & $\begin{array}{l}\text { Employment } \\
\text { Rate }\end{array}$ \\
\hline $\begin{array}{c}\text { So far, } 84 \\
\text { colleges and } \\
\text { universities in } \\
\text { our country have } \\
\text { information } \\
\text { security specialty } \\
\text { for } \\
\text { undergraduate. }\end{array}$ & $\begin{array}{l}\text { The } \\
\text { number of } \\
\text { information } \\
\text { security } \\
\text { graduates is } \\
\text { less than ten } \\
\text { thousand } \\
\text { people every } \\
\text { year. }\end{array}$ & $\begin{array}{c}\text { The total } \\
\text { social demand } \\
\text { has reached } 500 \\
\text { thousand } \\
\text { people. } \\
\text { Predictably in } \\
\text { the next five } \\
\text { year the annual } \\
\text { demand will } \\
\text { increase to about } \\
20 \text { thousand } \\
\text { people. }\end{array}$ & $\begin{array}{l}\text { In science or } \\
\text { engineering } \\
\text { subject, the } \\
\text { employment rate } \\
\text { of information } \\
\text { security rank to } \\
\text { the fourth. }\end{array}$ \\
\hline
\end{tabular}

Our Higher Education Law clearly defines that: "the task of higher education is to foster high-level professional talents with innovative spirit and practical ability". And this requires teachers that work on theorists and practitioners of higher engineering education recognize the current situation and pay highly attention to cultivate students' engineering innovative spirit and practical ability. Creative talents must have innovative thinking, however, the creative thinking of engineering and technical talents cannot come out of nowhere, and it depends on engineering practice and engineering practical ability training. Practice is the soul and the fundamental of engineering, the purpose of engineering education is to make the engineering college students return back to practice based on the basis of theoretical study, and face the real world, face the engineering practice and its real environment. Consequently foster high-quality professionals which have strong engineering practical ability. To achieve this training goal, theoretical basis education should be taken seriously, and at the same time broaden students' knowledge scope, face society, face practical engineering and education openly. Meanwhile, emphasize the reform of teaching contents and methods, strengthen experiment and practical education process, and enhance practical ability cultivation. This is the only way chosen to cultivate qualified engineering technical talents in the new period.

\section{Our Country Has Officially Joined "the Washington Accord", Which Put Forward New Demands for Information Security Engineering Education}

June 19, 2013, at the International Engineering Alliance Meeting held in Seoul, South Korea, China is accepted to "The Washington Accord" by the unanimous vote. Joining "The Washington Accord" indicates that the quality of engineering education has been recognized by the international engineering education fields. And it means the passport of the international mutual recognition quality guidelines provided, which is foundation to go abroad in the future. Colleges and universities that consistently emphasize improving the teaching quality firstly has a clear and reasonable reference frame. For our country, it marks that a specialty step towards the internationalization engineering education and consequently promote our country's engineering manufacturing go abroad and towards the world. In order to meet The Washington Accord better, a lot of work should be done, the current important task includes standardizing engineering practical education, combing professional curriculum system, defining graduate's cultivate goal and graduate requirement and formulating professional evaluation system .

\section{E. Cultivating College Students' Engineering Practical Ability Contributes to Improving Students' Comprehensive Quality}

Higher engineering education consists of teaching, application and innovation. The latter two parts not only help to cultivate ability but also help to achieve knowledge. Allow students to participate engineering practice appropriately, arrange guided knowledge application, and especially comprehensive knowledge applying, which can boost practical ability, comprehensive analysis ability and social adaptability, also can shorten the gap between self-pursuit and social requirement, and shorten the transition time from school to society. At the same time, allow students to participate in engineering practice, and closely combine moral education and intellectual education, theory and practice, knowledge and action, schools and society, educational and productive labor, etc. Which is benefit to break the traditional mode of self-enclosed engineering education, and enable students to enter a larger learning environment, and students can learn a lot of knowledge which can't acquire from books, classroom and school, consequently cultivate builders with comprehensive quality and excellent quality.

\section{INFORMATION SECURITY TEACHING PROBLEMS EXISTED}

Problem 1: Information security professional engineering practical ability is lack of systematicnessand comprehensiveness, and failed to link up with engineering education standards well.

systematicnessmeans that training objectives and training contents of engineering practical ability lack of overall planning. Comprehensiveness refers to the contents of engineering practical ability cultivation lack of intercross and interrelation among different courses and disciplines. Now for information security students, the practical ability cultivation mainly through courses setting or as a part of a course, practical ability developing is mainly distributed into different courses, so lack of systemic and comprehensive.

Problem 2: Lack of scientific information security professional ability evaluation system

Scientific information security professional development goals and graduate requirements are not taken as professional ability evaluation criteria. Perfect information security professional practical ability evaluation system, standardize structure and collect practical ability that information security profession graduates should have or develop. Complete the related standards which can be used to follow or reference in the teaching practice.

Problem 3: Lack of professional practical platform which meets industry developing requirement 
At present, for information security elementary laboratories, specialized laboratories and other laboratories, the common teaching method is to require students according to the guide books contents and steps to complete some replicationexperiments in the fixed time. Such as network security experiment course, the teaching content is by running several attack tools to view the attack phenomenon and results, however for the specific methods and design principles, students usually fail to deeply understand. Virtualization technology has largely been introduced into the current experiment teaching. In the network security experiment, because some experiments have damaging effects, or in order to save cost, so this kind of experiments mostly use computer to finish by virtualization technology. Virtual experiments rely on simulation software itself to verify. However for the feature without simulation that can't be verified. Engineering practice is hard to continue deeply. Most engineering internship companies are production-oriented enterprises, required continuous and stable production, and there are some technical confidentiality issues in some enterprises, so students can't deeply understand related techniques. In addition, in some companies, students are only permitted to look on some technical operations, rather than operate personally. Especially for some special technical steps, students cannot be present. During the engineering internship, it is difficult to deeply understand the nature of system for students. Information security engineering practice integrated platforms include research and practice, which explore and build comprehensive platform that reflect information security system architecture and include typical experimental system. Expand and deepen cooperation with enterprises, industry cooperation to enhance the engineering practice ability.

Problem 4: Teachers lack of engineering practice experience will influence teaching quality

Teaching staff structure and young teachers academic ability have a certain contrast with engineering practical ability. Usually pay attention to academic research and neglect engineering practice. Most university engineering teachers come from higher school's masters and doctor, for them there is no direct manufacture and practical experience. Meanwhile, due to higher school's management system and school-running model break away from society for a long period, so master and doctor cultivated by higher school have a problem that they are lack of a long time practice in the engineering industry.

\section{MEASURES OF REMEDIATION}

Measure 1: Reference to engineering education standards, combine social employment required, reform engineering practical education

First, take teachers' latest scientific and technological achievements to enrich course content and integrate with the knowledge available, which can help students to know the most cutting-edge scientific knowledge timely. Second, let students master interdisciplinary knowledge. In the traditional engineering education system in our country, the different disciplines are closely guarded. Therefore the reform is needed to break the boundaries between various disciplines, inject interdisciplinary knowledge, strengthen the integration of many courses, and design interdisciplinary courses and integrated curriculum.

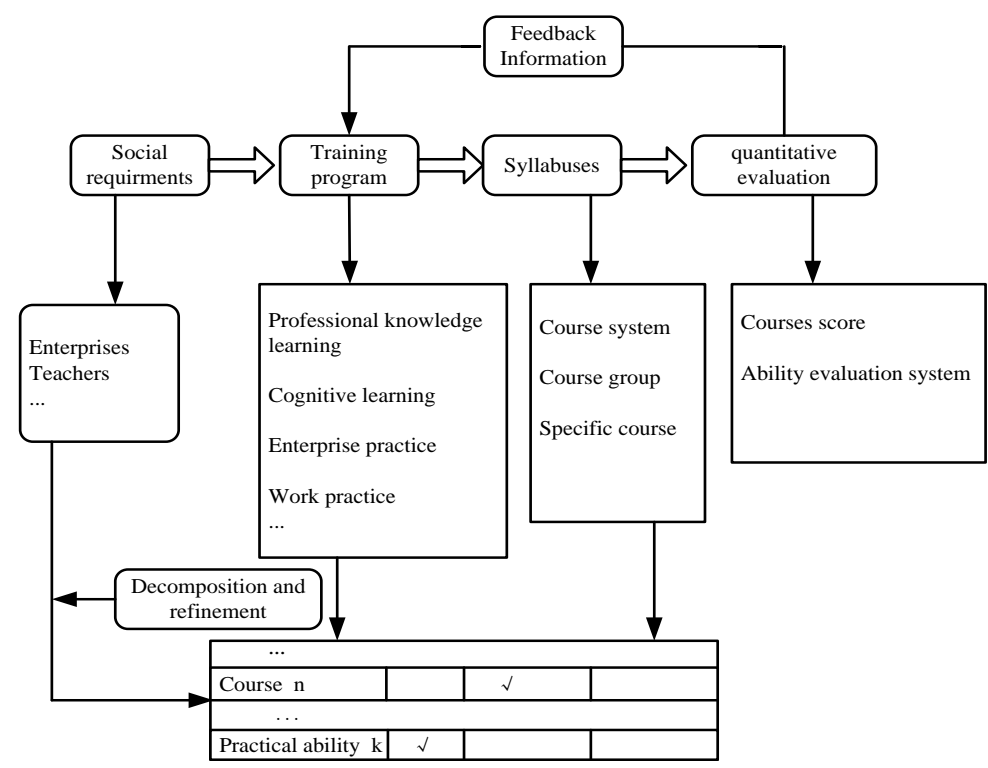

Fig. 1. Engineering practice ability cultivating idea.

All courses should build a platform of combineing theoryandpracticeby applying theory into practice, which is the fundamental requirement to cultivate students' engineering practical ability. In addition, for each course, especially engineering courses teaching, besides emphasize the basic subject knowledge, we should consistently enrich the engineering cases into the course content. In the professional education aspect, multistep cultivation scheme which consists of engineering consciousness, engineering personality and engineering ability is adopted. During the engineering consciousness cultivation phase, emphasize curriculum arrangement corresponding to the formation and development of knowledge capacity, and motivate students' potential engineering awareness. During the engineering 
personality formation phase, strengthen the corporation with well-known domestic and abroad enterprises. Take the mutual practice between enterprises and universities as main part and focus on the effectiveness of engineering personality. During the engineering ability forging phase, use the evaluation result of ability quantification as feedback index, rationally plan training method and accelerate the engineering ability speed, professional cultivation ideas as shown in Fig. 1.

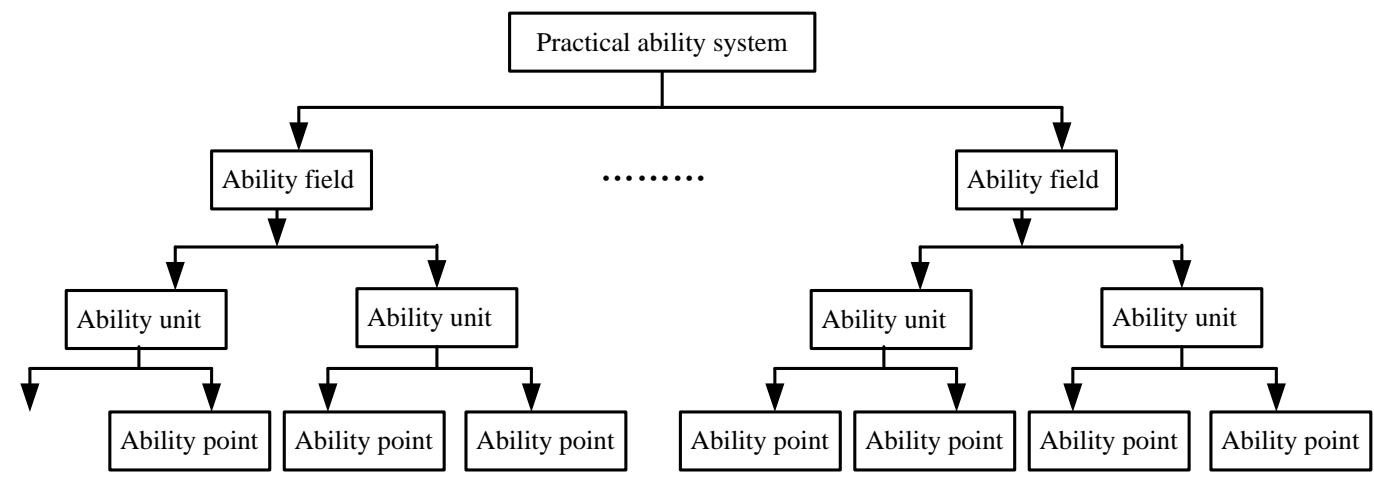

Fig. 2. Practical ability system.

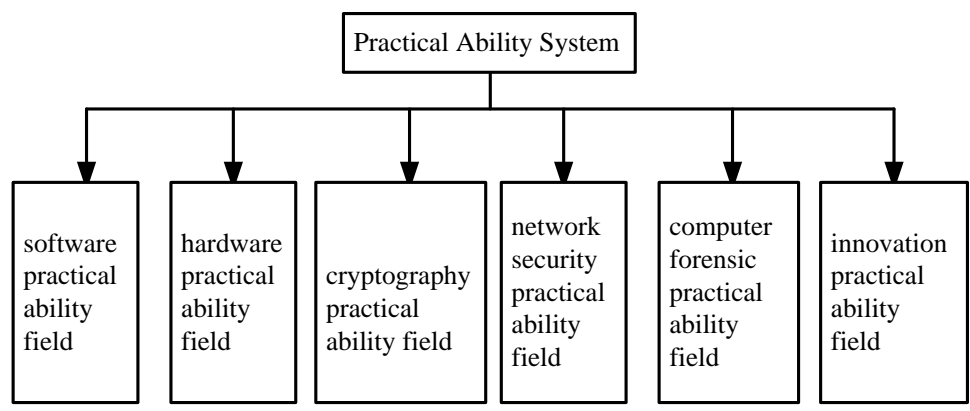

Fig. 3. Practical ability system structure.

Measure 2: Expand information security large enterprise cloud platform, school and enterprise cooperation platform, and enrich professional practical platform

By researching information security recruitment market , as well discussing with security enterprises employing department, overall considering the multiple needs of employment, classify graduation tendency into continue research, developing engineer, network security engineer, security test engineer and other targets. Then based on different targets to extract engineering ability index, establish a matrix which can reflect the relationship between courses and ability and establish professional practical platform plan which can adapt to the current industry development. Information security practice comprehensive platform can reflect information security system architecture and cover the comprehensive experimental platform of typical experimental system. According to "experiment, internship, training, practice" is layered teaching system, spirally carry out practical activities. Specifically, experiment and internship should cover all information security students. According to students' ability, interest and other factors, training and practices are organized and selected to maximize exploring the students' potential [5]-[8].

Build practice education resources platform that is based on Qihoo360 cloud platform.360cloudcomputing platform is a large cloud platform by cooperating with Qihoo360 to build a content-rich information security technology comprehensive learning and training platform. This platform includes building Applied Cryptography, Network Security, Computer Forensics and other information security professional core course learning resource platform. Practical platform is network security data platform, which includes software security testing practice platform, the website intrusion detection platform, firewall technology practice platform and other detail content.

Measure 3: Teaching staff engineering practical ability cultivation in the open form of subject collaboration and school-enterprise collaboration

According to the principle that profession and technique have priority and education background is subsidiary, introduce and employ industry experts, enterprise backbone to join teaching team as a part-time professional teachers and internship guide teachers. And cultivate them to involve in teaching directly, make up the defects that insufficient full-time teacher and the insufficient ability to solve practical problem, and create a teaching team combined with professional and part-time teacher.

By technique training, project management training, enterprise communication, profession construction tasks undertaken, core curriculum teaching implemented and other ways, enhance the project development and management comprehensive ability. Lead team to reform the training mode and curriculum system, and entirely improve the comprehensive quality of professional leaders and backbone teachers.

Based on technique training, participate in academic seminars at home and abroad, enterprise technical exchanges and cooperation. Take over enterprise engineering project or exchange project to provide professional and technical support for enterprise, and use techniques as cooperation 
priorities, and finally make cooperation relationship between schools and businesses closer.

Teachers are encouraged to participate in related project research of industry or companies in the form of half full-time. There are two forms: one is school-enterprise cooperation to carry out application technology research; the other one is the personnel involved research.

Strengthen practical ability of professional teachers. Plan to send professional teachers to cooperative enterprise to improve their practical ability, such as Qihoo 360, Chongqing iSoft Technology, etc. Encourage teachers to collaborate with enterprise to carry out application technology research or directly participate in enterprise research project, and support teachers as technician, technical manager, technical consultant and other part-time position in cooperative enterprise, and finally get industry qualification certificate.

Support professional teacher working in cooperative enterprises in the form of part-time job. Professional teacher can apply for the cooperative enterprise as technicians, technical management department managers, technical consultants, etc. The form can use full-time or part-time. Enterprises hire wage are not less than teacher's wage income. Teacher's salaries detained in accordance with the provisions give a certain percentage of rebates. Stimulate professional teachers exercise and practice in enterprise, and improve their abilities finally.

Measure 4: Refine practical ability hierarchy system, and develop scientific professional ability evaluation criteria (engineering practice section)

Building engineering practical ability evaluation system, from the relationship between the global and local perspective, practical ability system consists of practical ability field, practical ability unit and practical ability point. A practical ability field includes several practical ability units; a practical ability unit consists of several practical ability points. Fig. 2 shows the level division of practical ability system. According to different fields, professional practical ability can be divided into several parts: software practical ability field, hardware practical ability field, cryptography practical ability field, network security practical ability field, computer forensic practical ability field and innovation practical ability field. Fig. 3 shows the overall structure of the application-oriented information security professional practical ability system.

Practical ability system uses practical teaching system to cover, use practical teaching system to cultivate and improve students' practical ability. Practical teaching system consists of all kinds of practical teaching links; and practical ability system can have different coverage ways, so different practical teaching systems are available.

\section{SUMMARY}

Information security has become an important part of our national security. The information security talent education has been pushed to a new height of national strategy. However Information security talent education is lack of scientific information security professional ability evaluation system. Information security professional engineering practical ability education is lack of systematicnessand comprehensiveness, and lack of professional practical platform which can meet industry developing requirement. Furthermore teachers lack of engineering practice experience will influence teaching quality etc. In this paper the problems existed have been analyzed and the specific measures have been proposed. The education idea that is oriented student ability is proposed. The education center is transformed from teaching to studying, from knowledge system to ability standard to be reached. An open engineering practical ability education system is proposed. Taking the information security specialty education reform is necessary to cultivate the information security professionals to meet the social requirements.

\section{ACKNOWLEDGMENT}

I would like to thank Prof. Xia Ying and Prof. Chen Long meaningful suggestions and unselfish help.

\section{REFERENCES}

[1] J. Hu, "Firmly march on the path of socialism with Chinese characteristics and strive to complete the building of a moderately prosperous society in all respects," Report to the 18th National Congress of the Communist Party of China, Beijing Review, 2012, vol. 55.

[2] J. Lin, "Excellent engineering training plan general standard development," Higher Education Research, no. 4, pp. 21-29, 2010.

[3] Q. Kang, X.-H. Lu, and G.-J. Xiong, "CDIO outline and engineering innovative talent education," Higher Education Research, vol. 31, no. 4, pp. 15-18, 2008.

[4] M. Wu and G.-J. Xiong, Engineering Education Reform Research Oriented on Engineering Ability Training, vol. 29, no. 3, pp. 54-59, 2010.

[5] Information Security Specialty Reference Specification, Ministry of Education Information Security Class Specialty Education Steering Committee.

[6] Y. Xue, "CDIO combined with theory and practice-exploration of Tsinghua University innovative engineering education," no. 1, pp. 11-23, 2009.

[7] Z. Ti, X.-Q. Li, X. Li, and J. Wang, "Discussion on talents cultivation of engineering type soft-are with CDIO education pattern," Computer Education, no. 9, 39-40, 2010.

[8] S.-Xi. Li and G. D. Zhang, "A tentative study on innovative teaching mode and experimental teaching mode of information security specialty," Higher Education of Sciences, 2010.

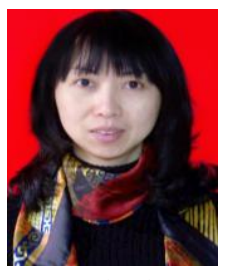

Wang Lian received the M.S. degree in computer and network engineering from London South University, London, UK, in 2004. And she is currently a Ph.D. candidate at Southwest Jiaotong University, Chengdu, China. She is an associate professor in the College of Computer Science and Technology, Chong Qing University of Posts and Telecommunications. Her research interests include network coding and wireless 